\author{
Serhiy Pysh'yev, Olexander Lazorko and Michael Bratychak
}

\title{
TEMPERATURE AND WATER EFFECT ON THE OXIDATIVE DESULPHURIZATION OF STRAIGHT-RUN DIESEL FRACTION WITH A HIGH SULPHUR CONTENT
}

Lviv Polytechnic National University, 12 St. Bandera str., 79013 Lviv, Ukraine

Received: J anuary 20, 2009

(C) Pysh’yev S., Lazorko O., Bratychak M. 2009

\begin{abstract}
The effect of temperature and water:raw material ratio on the oxidative desulphurization of straight-run diesel fraction $553-623 \mathrm{~K}$ has been examined. The optimum values of temperature and diesel fuel:water ratio for the raw material containing $0.87 \mathrm{wt} \%$ of sulphuric compounds have been determined.
\end{abstract}

Key words: desulphurization, diesel fuel, oxidative desulphurization, sulphur, sulphoxides, sulphones.

\section{Introduction}

The increasing demands for fuel ecological properties are the reason for the decrease of permissible amount of sulphuric compounds. At the same time the removal of sulphuric compounds (hydrofining) is the only one widely used industrial technology, which has a number of shortcomings:

- application of complicated equipment and purified hydrogen which is of short supply;

- removal of heteroatomic products and a part of aromatic hydrocarbons together with sulphuric compounds, resulting in the amount decrease of the products able to sorb over metal surfaces and lubricate them; removal.

- impossibility of some thiophene derivatives

All above-mentioned shortcomings require the development of novel technologies of oil fractions treatment, e.g. oxidative desulphurization. The essence of the method is the oxidation of sulphuric compounds to sulphones, sulphoxides and perhaps, sulphoacids with expressive polar properties. Such properties allow to separate them from other compounds using adsorption or extraction. Moreover, taking into account that sulphoxides, sulphones and sulphoacids have higher boiling temperatures compared with initial sulphuric compounds, they may be removed by usual distillation.
The known oxidative processes may be divided into three groups:

- technology aimed at fuel sweetening;

- processes with the aim of sulphoxides and sulphones obtaining;

- technology aimed at the decrease of total sulphur content.

The majority of works concerning the latter direction is aimed at the decrease of sulphur content to 5$15 \mathrm{ppm}$ in hydrofined fuels. At the same time the application of oxidative desulphurization for straight-run fractions allows to decrease sulphur amount by less than $80 \%$. Therefore it is impossible to produce fuel which meets the European standards (the sulphur content is 0.0005 0.0015 mas \%) from the raw material with the sulphur content more than 0.01 mas \%.

To date in Ukraine it is permitted to produce diesel fuels with the sulphur content prior to 0.2 mas $\%$. Such sulphur content may be achieved using oxidative desulphurization. Moreover such fuel has better lubricating properties and oxidation products (sulphuric concentrated compounds) may be used as lubricating fluids with a cost price higher by $10-20 \%$ than the price of commercial diesel fuels [1]. Thus, oxidative desulphurization of straightrun diesel fuels is attractive and perspective process from the point of view of diesel fuel production with the sulphur content prior to $0.2 \%$, as well as of lubricating properties improvement and obtaining of sulphuric concentrated compounds.

It has been shown earlier [2] that using wide straight-run diesel fraction (WDF) with the high sulphur content $(0.67 \mathrm{mas} \%)$ it is necessary to desulphurize at least two parts of WDF - the "head" fraction (start boiling point-553 K) and the "tail" fraction (553-623 K). Since the "tail" fraction is heavier than the "head" one, the oxidation degree is less and it is necessary to use the combination of several methods (e.g. rectification and adsorption) to remove the oxidation products. At the same 
time the combination of two methods is a bulky and long process.

On the other hand (Table 1), the tendency of factors effect on the process proceeding is preserved without regard to any methods of oxidation products removal or combination of the methods. It means that we can use rectification only in order to simplify the technique of laboratory experiments and decrease their duration.

Since it has been shown in [1-2] that the presence of water may increase the selectivity of sulphuric compounds oxidation, it was necessary to establish the dependence of process characteristics upon its main factors - temperature and raw material:water ratio.

\section{Experimental}

Raw material with boiling temperatures ranging from 553 to $623 \mathrm{~K}$ obtained from WDF with the sulphur content $0.67 \mathrm{mas} \%$ has been used for the investigations. The characteristics of raw material are represented in Table 2.

The fraction oxidation was studied at high temperatures and pressure using enlarged laboratory plant, the scheme of which is represented in [3]. The experimental technique and plant description are presented in [1-3]. After oxidation the water phase was separated and oxidated straight-run fraction (oxidate) was divided and analyzed by the following scheme (Fig. 1).

The raw material and oxidation products were analyzed using standard methods for determination of total sulphur content [4], soluble gums content [5] and acidity [6].
Air was used for the oxidation of initial fraction. Raw material:air ratio, as well as process time were sustained constant during oxidation.

In order to determine the optimum pressure the strippant part was calculated at different pressures and maximum temperature of previous investigations $(513 \mathrm{~K})$ both in the presence of water and without it.

The amount of raw material vapors from the reactor is determined by the formula:

$$
\mathrm{G}=\left(\mathrm{g}_{\mathrm{air}} \cdot \mathrm{P}_{\mathrm{svp}} \cdot \mathrm{M}\right) /\left(\mathrm{P}-\mathrm{P}_{\mathrm{svp}}\right) / 29
$$

where $M$ is the molecular mass of vapors mixture of straight-run diesel fraction and water; $g_{\text {air }}$ is the amount of air which passes throughout the reactor, $\mathrm{kg} ; P_{s v p}$ is saturation vapor pressure for the mixture of straight-run diesel fraction and water (when it is present), $\mathrm{Pa} ; P$ is a general pressure in the reactor, $\mathrm{Pa} ; 29$ is the molecular mass of air.

According to (1) the graphic dependence of the amount of strippant vapors with air upon general pressure in the reactor (Fig. 2) at $513 \mathrm{~K}$ was plotted. One can see from Fig. 2 that at $513 \mathrm{~K}$ and pressures up to $3 \mathrm{MPa}$ in the presence of water the strippant part is relatively large, resulting in possible considerable losses of straight-run fraction with air. The increase of pressure in the reactor over $3 \mathrm{MPa}$ does not affect the decrease of strippant part. In connection with this fact, the used air after the reactor passed through a cooling condenser and cooled to $313 \mathrm{~K}$ in order to decrease the losses. Due to such cooling the part of straight-run diesel fraction vapors condensed and returned back to the reactor. In accordance with analogous calculations the part of strippant with air will not exceed

Effect of oxidate liquid phase separation methods on the sulphur content

Table 1 in the refined fuel changing process factor

\begin{tabular}{|c|c|c|c|}
\hline \multirow{3}{*}{$\begin{array}{l}\text { Oxidate liquid phase separation } \\
\text { method }\end{array}$} & \multicolumn{3}{|c|}{ Content of total sulphur in therefined fuel, mas $\%$} \\
\hline & \multicolumn{3}{|c|}{ at temperatures } \\
\hline & $453 \mathrm{~K}$ & $473 \mathrm{~K}$ & $553 \mathrm{~K}$ \\
\hline Distillation & 0.65 & 0.61 & 0.68 \\
\hline Adsorption & 0.64 & 0.59 & 0.63 \\
\hline \multirow[t]{3}{*}{ Distillation-adsorption-distillation } & 0.29 & 0.24 & 0.35 \\
\hline & \multicolumn{3}{|c|}{ With/without water } \\
\hline & Without water & \multicolumn{2}{|r|}{ With water } \\
\hline Distillation & 0.65 & \multicolumn{2}{|r|}{0.65} \\
\hline Adsorption & 0.64 & \multicolumn{2}{|r|}{0.63} \\
\hline Distillation-adsorption-distillation & 0.29 & \multicolumn{2}{|r|}{0.26} \\
\hline
\end{tabular}

Characteristics of initial fractions

Table 2

\begin{tabular}{|l|c|}
\hline \multicolumn{1}{|c|}{ Index } & Value \\
\hline Density at $293 \mathrm{~K}, \mathrm{~kg} / \mathrm{m}^{3}$ & 856 \\
\hline Content of total sulphur, mas \% & 0.87 \\
\hline Concentration of soluble gums, $\mathrm{mg} / 100 \mathrm{~cm}^{3}$ & 15.0 \\
\hline Yield, mas \% to calculate for wide straight-run diesel fraction & 35.3 \\
\hline
\end{tabular}




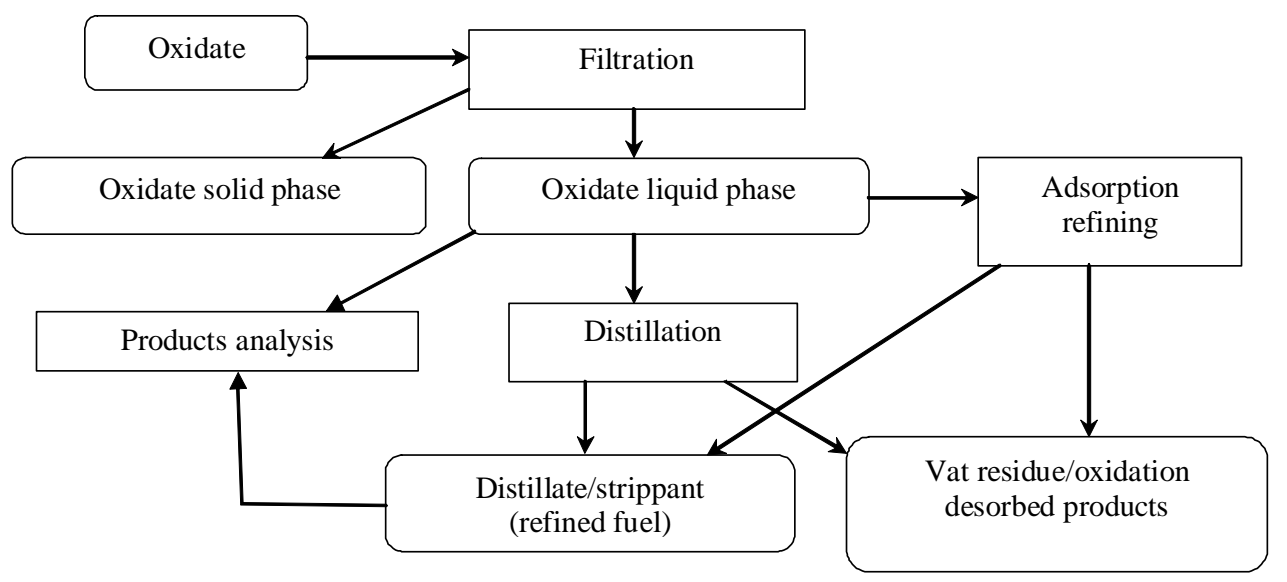

Fig. 1. Scheme of oxidate division and investigation

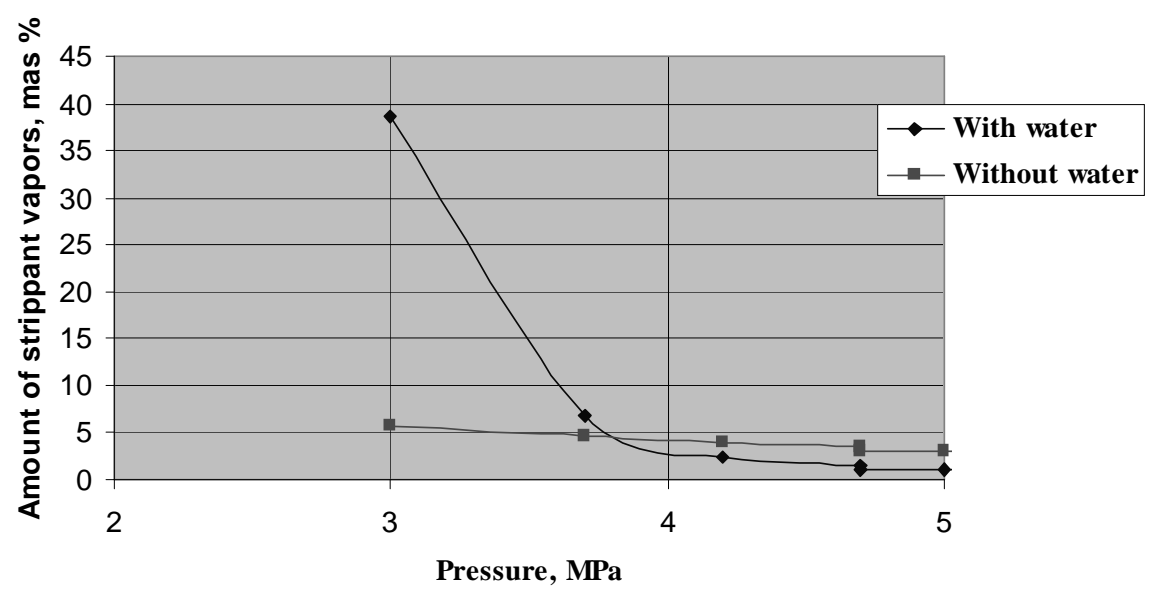

Fig. 2. Dependence of strippant part upon pressure at $513 \mathrm{~K}$

$0.002 \%$ even at $0.5 \mathrm{MPa}$ at the possible temperature of the used air $313 \mathrm{~K}$.

Taking into account above-mentioned, the pressure of approximately $3 \mathrm{MPa}$ was sustained in all experiments. Such pressure ensured the liquid state of the main part of reactive medium within all investigated temperature range and minimum losses of raw material with the used air.

The losses during distillation of oxidate liquid phase were neglected at the calculations of material balances.

\section{Results and Discussion}

The results of temperature effect on the process proceeding are represented in Tables 3-5 and Fig. 3. The experiments were carried out without water.

As mentioned in Section 2, the soluble gums content and liquid phase acidity of oxidate and distillate (purified fuel) were determined for the analysis of oxidation degree of hydrocarbon raw material. The first value characterizes the amount of formed condensation and oxidation products which are inclined to further condensation and gumming during operation or storage; the second value is the amount of acid soluble in the fuel components.

One can see from obtained results that the increase of temperature favors the increase of oxidation and condensation rates of sulphuric compounds as well as hydrocarbons. The yields of oxidate solid phase (products of final oxidation and condensation) and vat residue (concentrate of oxidized sulphuric compounds and liquid products of hydrocarbons oxidation) increase.

The soluble gums content, acidity of oxidate liquid phase and oxidate distillation products also increase at temperatures prior to $513 \mathrm{~K}$. The decrease of acidity and soluble gums content at $553 \mathrm{~K}$ (compared with $513 \mathrm{~K}$ ) is explained by the fact that condensation and oxidation processes proceed more deeply - the majority of oxidized and condensed structures is separated as the solid phase and vat residue, pro tanto less oxidation products remain.

The maximum sulphur removal degree for the purified fuel is achieved at $493 \mathrm{~K}$. The following increase of temperature decreases the removal degree since the oxidation degree and accordingly, the sulphuric compounds removal, actually do not change at the 
Temperature effect on the products yield

Table 3

\begin{tabular}{|c|c|c|c|c|c|}
\hline \multirow[b]{2}{*}{ No } & \multirow[b]{2}{*}{ Temperature, $\mathrm{K}$} & \multicolumn{4}{|c|}{ Yield, mas \% calculated for raw material } \\
\hline & & $\begin{array}{c}\text { Oxidate liquid } \\
\text { phase }\end{array}$ & $\begin{array}{c}\text { Oxidate solid } \\
\text { phase }\end{array}$ & $\begin{array}{c}\text { Distillate } \\
\text { (refined fuel) }\end{array}$ & Vat residue \\
\hline 1 & 433 & 98.39 & 1.58 & 94.26 & 4.13 \\
\hline 2 & 453 & 97.22 & 2.39 & 91.94 & 5.28 \\
\hline 3 & 473 & 95.93 & 2.71 & 90.56 & 5.37 \\
\hline 4 & 493 & 95.37 & 3.08 & 89.84 & 5.53 \\
\hline 5 & 513 & 95.49 & 3.59 & 88.76 & 6.73 \\
\hline 6 & 553 & 95.52 & 4.03 & 87.88 & 7.64 \\
\hline
\end{tabular}

Temperature effect on the quality of oxidate liquid phase

\begin{tabular}{|c|c|c|c|c|}
\hline \multirow[b]{2}{*}{ No } & \multirow[b]{2}{*}{ Temperature, K } & \multicolumn{3}{|c|}{ Index } \\
\hline & & $\begin{array}{c}\text { Content of total sulphur, } \\
\text { mas } \%\end{array}$ & $\begin{array}{l}\text { Concentration of soluble } \\
\text { gums, mg/100 cm }\end{array}$ & $\begin{array}{c}\text { Acidity, } \\
\mathrm{mg} \mathrm{KOH} / 100 \mathrm{sm}^{3}\end{array}$ \\
\hline 1 & 433 & 0.83 & 124 & 38.2 \\
\hline 2 & 453 & 0.83 & 237 & 45.4 \\
\hline 3 & 473 & 0.82 & 284 & 67.0 \\
\hline 4 & 493 & 0.8 & 463 & 167.0 \\
\hline 5 & 513 & 0.72 & - & - \\
\hline 6 & 553 & 0.73 & - & - \\
\hline
\end{tabular}

Temperature effect on the quality of refined fuel

Table 5

\begin{tabular}{|c|c|c|c|c|}
\hline \multirow{2}{*}{ No } & \multirow{2}{*}{ Temperature, $\mathrm{K}$} & \multicolumn{3}{|c|}{ Index } \\
\cline { 3 - 5 } & 433 & $\begin{array}{c}\text { Content of total sulphur, } \\
\text { mas } \%\end{array}$ & $\begin{array}{c}\text { Concentration of soluble } \\
\text { gums, } \mathrm{mg} / 100 \mathrm{~cm}^{3}\end{array}$ & $\begin{array}{c}\text { Acidity, } \\
\mathrm{mg} \mathrm{KOH} / 100 \mathrm{sm}^{3},\end{array}$ \\
\hline 1 & 453 & 0.74 & 25.6 & 4.2 \\
\hline 2 & 473 & 0.65 & 41 & 10.5 \\
\hline 3 & 493 & 0.61 & 42.3 & 23.7 \\
\hline 4 & 513 & 0.58 & 47.5 & 44.2 \\
\hline 5 & 553 & 0.64 & 64 & 57.3 \\
\hline 6 & & 0.68 & 33 & 52.1 \\
\hline
\end{tabular}

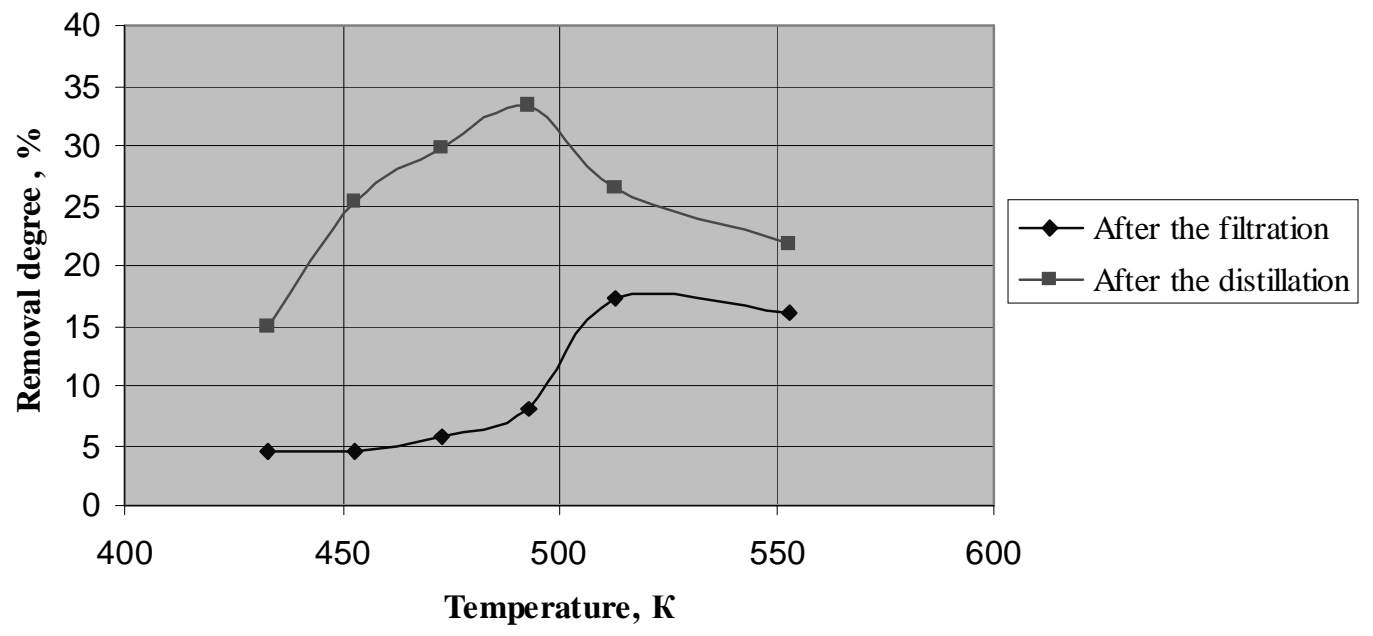

Fig. 3. Dependence of sulphur removal degree upon process temperature 
Temperature and Water Effect on the Oxidative Desulphurization of Straight-Run Diesel Fraction... 167

Effect of water:raw material ratio on the products yield

Table 6

\begin{tabular}{|c|c|c|c|c|c|}
\hline \multirow{2}{*}{ No } & \multirow{2}{*}{\begin{tabular}{c} 
Water:raw material ratio \\
\cline { 2 - 5 }
\end{tabular}} & $\begin{array}{c}\text { Oxidate liquid } \\
\text { phase }\end{array}$ & $\begin{array}{c}\text { Oxidate solid } \\
\text { phase }\end{array}$ & $\begin{array}{c}\text { Distillate } \\
\text { (refined fuel) }\end{array}$ & Vat residue \\
\hline 1 & $0: 1$ & 97.22 & 2.39 & 91.94 & 5.28 \\
\hline 2 & $1: 10$ & 98.53 & 0.64 & 93.38 & 5.15 \\
\hline 3 & $1: 5$ & 98.65 & 0.28 & 93.77 & 4.88 \\
\hline 4 & $1: 2.5$ & 98.21 & 0.23 & 93.64 & 4.57 \\
\hline 5 & $1: 1$ & 98.01 & 0.21 & 93.57 & 4.44 \\
\hline 6 & $2: 1$ & 98.13 & 0.21 & 93.45 & 4.68 \\
\hline 7 & $7: 1$ & 96.59 & 0.19 & 92.34 & 4.25 \\
\hline 8 & $9: 1$ & 96.02 & 0.15 & 91.73 & 4.29 \\
\hline
\end{tabular}

Effect of water:raw material ratio on the quality of oxidate liquid phase

\begin{tabular}{|c|c|c|c|c|}
\hline \multirow{2}{*}{ No } & Water:raw material ratio & \multicolumn{3}{|c|}{ Index } \\
\cline { 3 - 5 } & & $\begin{array}{c}\text { Content of total } \\
\text { sulphur, mas \% }\end{array}$ & $\begin{array}{c}\text { Concentration of soluble } \\
\text { gums, } \mathrm{mg} / 100 \mathrm{~cm}^{3}\end{array}$ & $\begin{array}{c}\text { Acidity, } \\
\mathrm{mg} \mathrm{KOH} / 100 \mathrm{sm}^{3}\end{array}$ \\
\hline 1 & $0: 1$ & 0.83 & 237 & 45.4 \\
\hline 2 & $1: 10$ & 0.80 & 86 & 44.0 \\
\hline 3 & $1: 5$ & 0.78 & 82 & 41.5 \\
\hline 4 & $1: 2.5$ & 0.77 & 63 & 40.1 \\
\hline 5 & $1: 1$ & 0.81 & 41 & 33.55 \\
\hline 6 & $2: 1$ & 0.82 & 35 & 22.6 \\
\hline 7 & $7: 1$ & 0.85 & 18 & 11.3 \\
\hline 8 & $9: 1$ & 0.84 & 19 & 11.2 \\
\hline
\end{tabular}

Effect of water:raw material ratio on the quality of refined fuel

Table 8

\begin{tabular}{|c|c|c|c|c|}
\hline \multirow{2}{*}{ № } & Water:raw material ratio & \multicolumn{3}{|c|}{ Index } \\
\cline { 3 - 5 } & $0: 1$ & $\begin{array}{c}\text { Content of total } \\
\text { sulphur, mas } \%\end{array}$ & $\begin{array}{c}\text { Concentration of } \\
\text { soluble gums, } \\
\mathrm{mg} / 100 \mathrm{~cm}^{3}\end{array}$ & $\begin{array}{c}\text { Acidity, } \\
\mathrm{mg} \mathrm{KOH} / 100 \mathrm{sm}{ }^{3},\end{array}$ \\
\hline 1 & $1: 10$ & 0.65 & 41 & 10.5 \\
\hline 2 & $1: 5$ & 0.65 & 26 & 7.3 \\
\hline 3 & $1: 2.5$ & 0.62 & 27 & 5.1 \\
\hline 4 & $1: 1$ & 0.63 & 22 & 4.9 \\
\hline 5 & $2: 1$ & 0.65 & 20 & 4.1 \\
\hline 6 & $7: 1$ & 0.67 & 18 & 3.4 \\
\hline 7 & $9: 1$ & 0.80 & 10 & 1.3 \\
\hline 8 & & 0.80 & 10 & 1.2 \\
\hline
\end{tabular}

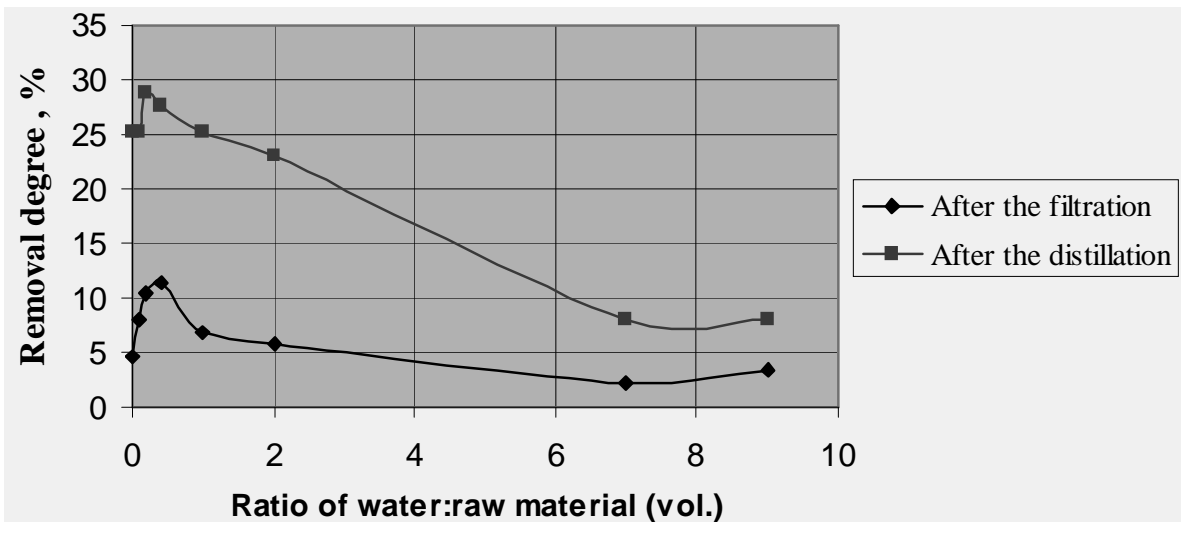

Fig. 4. Dependence of sulphur removal degree upon water:raw material ratio 
temperatures of above $493 \mathrm{~K}$, i.e. mass amount of such compounds in the purified product is constant.

Thus temperatures $453-493 \mathrm{~K}$ are the optimum temperatures.

The results concerning the effect of water are represented in Tables 6-8 and Fig. 4.

One can see that introduction of water into reaction medium inhibits the oxidation of hydrocarbon medium: soluble gums content, acidity of obtained products and yields of oxidation products (oxidate solid phase and vat residue) decrease. On the other hand, small portions of water practically do not influence the sulphuric compounds oxidation rate. Due to the increase of fuel yield the sulphur removal degree increases even at the water:raw material ratio $1: 5$ and $1: 2.5$.

At water:raw material high ratio (7:1 and 9:1) the fuel and oxidate yields decrease owing to the losses of raw material with water vapors and solubility of oxidation products in aqueous phase.

Depending on the fact that the increase of water amount decreases reactor productivity and increases its sizes, the optimum water:raw material ratio is 1:10-1:5.

\section{Conclusions}

It has been established that $453-493 \mathrm{~K}$ is the optimum temperature range for the oxidative desulphurization of 553-623 K fraction with the sulphur content of 0.87 mas \%. The introduction of small amount of water (water:raw material ratio is 1:10-1:5) positively affects the process selectivity, essentially decreases the oxidation of hydrocarbon medium and does not change the sulphuric compounds oxidation rate.

\section{References}

[1] Paniv P.: PhD thesis, Lviv 2002.

[2] Lazorko O., Bratychak M. and Pysh'yev S.: Chem. \& Chem. Techn., 2008, 2, 309.

[3] Antonyshyn V. and Gumenetskyy V.: Visnyk NU "LP". Khimiya i Khimichna Tehnologiya, 1974, 82, 94.

[4] State standards GOST 19121-73.

[5] State standards GOST 8489-85.

[6] State standards GOST 5985-79.

\section{ВПЛИВ ТЕМПЕРАТУРИ ТА ВОДИ НА ПРОЦЕС ОКСИДАЦЙНОГО ЗНЕСІРЧУВАННЯ ПРЯМОГОННОЇ ДИЗЕЛЬНОЇ ФРАКЦІЇ З ВИСОКИМ ВМІСТОМ СІРКИ}

Анотація. Вивчено вплив температури та співвідношення вода:сировина на прочес оксидаційного знесірчування прямогонної дизельної фракції 553-623 К. Встановлено оптимальні значення температури та співвідношення вода:дизельна фракція для сировини, щзо містить 0,87 \% мас. сірчистих сполук.

Ключові слова: десульфуризація, дизельне пальне, оксидацій не знесірчування, сірка, сульфоксиди, сульфони. 